\title{
Fiber Quality of Iranian Carpet-Wool Sheep Breeds
}

\author{
H. R. Ansari-Renani \\ Animal Science Research Institute \\ P. O. Box. 31585-1483, Karaj I. R. Iran \\ (Received 03-08-2012; Reviewed 26-11-2012; Accepted 03-12-2012)
}

\begin{abstract}
This experiment was aimed to identify characteristics and comparative merits of Iranian sheep wool breeds. Fiber characteristics of 75 male and 137 female of 1, 2, 3 and $4 \mathrm{yr}$ of age belonging to Afshari, Zandi, Mehrabani, Lori, and Baluchi sheep breeds were studied. Samples of fiber were taken from the left midside of sheep and analyzed using standard objective measurements for staple length (SL), mean fiber diameter (MFD), coefficient of variation of fiber diameter (FDCV), inner coat fiber ICF, outer coat fiber (OCF), kemp fiber (KF) and yield (Y). A general linear model including sex and age as fixed effects and breed as random effect was used to analyze the data. The mean (and s.e) for SL, MFD, FDCV, ICF, OCF, KF and Y were $110.8 \pm 0.1 \mathrm{~mm}, 36.9 \pm 0.5 \mu \mathrm{m}, 50.2 \% \pm 0.8 \%, 84.2 \% \pm 0.6 \%$, $9.8 \% \pm 0.4 \%, 5.9 \% \pm 0.4 \%$ and $69.3 \% \pm 0.7 \%$ respectively. MFD of $22 \%$ of all wool samples was between $22-30 \mu \mathrm{m}$. MFD of a further $36 \%$ and $42 \%$ of wool samples was between $31-37 \mu \mathrm{m}$ and coarser than $37 \mu \mathrm{m}$. SL of $12 \%$ of wool samples was shorter than $100 \mathrm{~mm}$ and $38 \%$ of samples between $100-120$ $\mathrm{mm}$ and $50 \%$ of samples were longer than $120 \mathrm{~mm}$. There is substantial scope to improve the quality of fiber produced by Iranian sheep breeds through genetic selection.
\end{abstract}

Key words: sheep, wool, staple length, fiber diameter, fiber types

\section{ABSTRAK}

Penelitian ini bertujuan untuk mengidentifikasi karakteristik dan membandingkan keunggulan domba tipe wool Iran. Karakteristik serat dari 75 ekor jantan dan 137 betina umur 1, 2, 3, dan 4 tahun bangsa domba Afshari, Zandi, Mehrabani, Lori, dan Baluchi diamati pada penelitian ini. Sampel serat diperoleh dari sisi tengah kiri domba dan dianalisa menggunakan pengukuran secara objektif untuk panjang serabut (SL), diameter serat tengah (MFD), koefisien keragaman diameter serat (FDCV), serat lapisan dalam (ICF), serat lapisan luar (OCF), serat kemp (KF), dan perolehan serat (Y). Nilai tengah (dan standar error) untuk SL, MFD, FDCV, ICF, OCF, KF, dan Y secara berurutan adalah 110,8 $\pm 0,1$ $\mathrm{mm}, 36,9 \pm 0,5 \mu \mathrm{m} ; 50,2 \% \pm 0,8 \% ; 84,2 \% \pm 0,6 \% ; 9,8 \% \pm 0,4 \% ; 5,9 \% \pm 0,4 \%$; dan $69,3 \% \pm 0,7 \%$. MFD $22 \%$ dari seluruh sampel wol adalah 22-30 $\mu \mathrm{m}$. MFD 36\% dari sampel wol adalah antara 31-37 $\mu \mathrm{m}$ dan $42 \%$ lebih dari $37 \mu \mathrm{m}$. SL dari $12 \%$ sampel wol lebih pendek dari $100 \mathrm{~mm}, 38 \%$ sampel antara $100-120 \mathrm{~mm}$, dan $50 \%$ sampel lebih panjang dari $120 \mathrm{~mm}$. Karakteristik tersebut merupakan lingkup penting untuk meningkatkan kualitas serat yang dihasilkan bangsa-bangsa domba Iran melalui seleksi genetik.

Kata kunci: domba, wol, panjang serabut, diameter serat, tipe serat

\section{INTRODUCTION}

Sheep population of Iran was 53.8 million heads in 2008 which ranks $5^{\text {th }}$ rank in the world (FAO, 2010) with 27 well defined breeds. This population of sheep produced annually about 400,000 tones of meat, 820,000 tones of milk, 60,000 tones of wool, 22 million skin pelts and 188,000 tones of guts (Ministry of Agriculture, 2009).

*Corresponding author:

E-mail: ansarirenani@yahoo.com
More than 1.6 million people are directly involved in sheep breeding with significant role in the economy and livelihood of rural and nomadic societies.

Four major sheep production systems can be distinguished: rural, nomadic, semi-intensive and intensive systems with major concentration on rural and nomadic systems. Semi-intensive system predominantly includes fattening of sheep in large farms, whereas in intensive system, sheep is raised in large agro-industries run by public holdings and cooperatives. On average every rural/nomad household keeps about 95 heads of sheep. More than $96.3 \%$ of Iranian sheep population belongs to the fat tailed and the remaining $4 \%$ belong to semi-fat 
tailed and tailed breeds. "Zel" is the only tailed breed and the semi-fat tailed breeds are Taleshi and Dalagh (Atabai) which live in northern areas near Caspian Sea.

Sheep are well adapted to local environmental conditions (Yilmaz et al., 2003) and Iranian indigenous breeds are dual purpose in which wool comes second after meat production in the farmer's priority and sold in the local market. Wool produced by sheep breeds plays an important role both as an important source of income to farmers and as a supply of raw material for hand-woven carpet. Iran has exported 8 million square meters of hand-woven carpets annually during last two decades.

All Iranian sheep breeds are double-coated and produce carpet wools which contain some proportion of hollow or medullated coarse and resilient hair and kemp fibers and are used in the manufacture of carpets. The fleece of sheep grows from specialized follicles in the skin. While primary follicles bear medullated outer coat coarse fiber (hair) and provide mechanical protection, secondary follicles produce non-medullated inner coat fine fiber or true-wool which provides thermal protection. The fiber diameter and staple length are the most important characteristics. Carpet wool quality and its value are primarily determined by fiber diameter and length which reflect the degree of wool growth and fineness respectively. Presently, little technical data is available on Iranian sheep fiber characteristics. Accordingly this paper studies wool quality and its variation of different sheep breeds in different regions of Iran in order to determine the scope for improvement and future utility.

\section{MATERIALS AND METHODS}

\section{Animals and Procedures}

A total of 212 sheep (75 males and 137 females) of Afshari, Zandi, Mehrabani, Lori and Baluchi breeds respectively from Zanjan, Qom, Hamedan, Lorestan, and South Khorasan provinces were used in this study. The sheep grazed all year but their diets were supplemented during winter with limited amount of forage and grain (containing $15 \mathrm{~g} \mathrm{~N} \mathrm{~kg}^{-1}$ dry matter and 9.1 MJ) and were housed at night during severe weather conditions. Sheep were grouped into 4 age groups: 1, 2, 3, and 4 yr old.

Wool sampling coincided with the maximum wool growth prior to the shearing of wool. In order to facilitate sampling, sheep were restrained in a lateral position and about 10 grams of fiber containing hair, kemp (medullated) and true wool (non-medullated) from the left mid-side site was cut from a $5 \times 5 \mathrm{~cm}^{2}$ close to the skin using regular scissors. Mid-side samples are common when fleece traits are considered (Ahtash, 2005; Cimen, 2006). Each sample was separately packaged and labeled with ear tag number, age, gender and the breed of the sheep.

Fiber characteristics of raw wool samples were measured in the Animal Science Research Institute Fiber Laboratory in Karaj, Iran. A quarter of each sample was weighed with a digital scale. Contaminants such as dan- druff, vegetable matter, scurf and soil were separated. To determine the percentage of clean wool weight, net bags containing samples without contaminants were weighed immediately, immersed in three scouring bowls solution containing $0.3 \%$ of $\mathrm{Na}_{2} \mathrm{CO}_{3}$ and $0.1 \%$ of soap and water and stirred for 15 minutes at a temperature of $52 \pm 3{ }^{\circ} \mathrm{C}$. This procedure was repeated once more but only with warm water. Washed samples were oven-dried and weighed and the percentage of clean wool weight was estimated. The mean fiber diameter of the washed wool sample was measured using a projection microscope. The average staple length for each wool sample (in triplicates) was measured to the nearest $0.1 \mathrm{~cm}$. The number of non-medullated inner coat fiber, medullated outer coat hair fiber and medullated kemp fiber were measured (IWTO, 1952).

\section{Statistical Analysis}

Analysis of variance was performed using a general linear model. Differences between means were tested using Duncan's new multiple range test. The statistical model used for cashmere goats of different age, sex and breed was:

$$
Y_{i j k}=\mu+\alpha_{i}+S_{j}+B_{k}+(\alpha S)_{i j}+(\alpha B)_{i k}+(S B)_{j k}+(\alpha S B)_{i j k}+\varepsilon_{i j k}
$$

where: $Y_{i j k}$ : dependent variables; $\mu$ : the overall mean; $\alpha_{i}$ : the effect of age $(i=1,2,3,4)$; $S_{j}$ : the effect of $\operatorname{sex}(j=1,2)$; $B k$ : the effect of breed $(k=1,2,3,4,5), \varepsilon_{i j k}$ : residual error; $(\alpha S)_{i j}$ : interaction between age and sex groups; $(\alpha B)_{i k}$ : interaction between age and breed groups; $(S B)_{j k}$ : interaction between sex and breed groups; $(\alpha S B)_{i j k}$ : interaction between age, sex and breed groups.

All values were expressed as least square means \pm SEM with $\mathrm{P}<0.05$ was considered to be statistically significant.

\section{RESULTS AND DISCUSSION}

For the measured wool characteristics total mean and standard errors are provided for different breeds, sexes and ages (Table 1), minimum and maximum values are given (Table 2) and different ranges of fiber are shown (Table 3 ). Twenty two and $36 \%$ of all wool samples had a fiber diameter between 22-30 and 31-37 $\mu \mathrm{m}$ respectively. A further $42 \%$ of the wool samples were coarser than $37 \mu \mathrm{m}$. All samples were longer than $80 \mathrm{~mm}$ but shorter than $147 \mathrm{~mm}$ with $12 \%$ less than 100 $\mathrm{mm}, 38 \%$ between 100 and $120 \mathrm{~mm}$ and 50\% longer than $120 \mathrm{~mm}$. $67 \%$ of all samples had a percentage of inner coat fiber greater than 80 while 28 and 5\% of wool samples had a non-medullated inner coat fiber percentage of 65-80 and less than 65 respectively.

\section{Yield and Percentage of Wool Types}

Average yield was $69.3 \% \pm 0.7 \%$ (Table 1 ) with an individual sheep range of $30.9 \%$ to $87.4 \%$ (Table 2). Males and one year old sheep had significantly higher percent- 
age of yield than females and older sheep. Zandi breed had $63.2 \% \pm 1.6 \%$ of yield which was the highest among the breeds.

The average percentages of inner coat, outer coat and kemp fibers were $84.2 \% \pm 0.6 \%, 9.8 \% \pm 0.4 \%$, and $5.9 \% \pm 0.4 \%$ respectively (Table 1 ). There was no significant difference in the percentage of inner coat fiber between male and female sheep. However one year old sheep with $87.3 \%$ had highest inner coat fiber than older sheep. Zandi breed with $93.7 \% \pm 1.9 \%$ had significantly highest inner coat fiber than other sheep breeds.

The $9.8 \%$ medullated OCF in the present study is similar to that reported for Arabi (10.9\%) (Ashmawi \& El-Azzawy, 1980), lower than those in the Awassi sheep in Jordan and Iraq (12\%) (Tabbaa et al., 2001), Moghani sheep in Iran (18.36\%) (Farahvash et al., 2010) and higher than those in the Ossimi (5.3\%) and Rahmani $(2.3 \%)$ sheep (Maria et al., 1992), Arkhamerino $\times$ Ghezel and Arkhamerino $\times$ Moghani crossbred sheep $(7.1 \%$ and 8.1\% respectively) (Esfandyari et al., 2011), Ghezel sheep (9.42\%) (Farahvash et al., 2010). Proportion of medullated fiber in fine wool breeds is about $0.1 \%-0.5 \%$ (Lupton et al., 2004). The amount of medullated fibers in current study falls within the range of $5 \%-25 \%$ reported for carpet-wool breeds in Asia (Mehta et al., 2004). No significant difference in inner coat fiber percentage between males and females of Iranian breeds of the present study was in agreement with the findings of Jordanian Awassi sheep breed. Tabbaa et al. (2001) reported 11\% and 10\% medullated inner coat fiber for male and female Awassi lambs respectively. One year old sheep had highest percentage of inner ICF percentage and decreased with age. Tabbaa et al. (2001) also reported that the percentage of inner coat decreased with advancing age in Awassi and Barki sheep breeds. One year old sheep had the lower percentage of kemp fiber than older sheep, a finding in agreement with Awassi sheep (Tabbaa et al., 2001).

Large variation in the percentage of $\mathrm{KF}$ was found between breeds of sheep which is in agreement with the findings of Wurzinger et al. (2005), Mokhber (2005) and Safari et al. (2005). Large variation in the percentage of ICF (58.9\%-98.6\%) and undesirable KF (0\%-33.6\%) demonstrate the possibility for improving Iranian sheep fleece quality by selection. Farmers need to be trained on selection criteria for breeding rams based on subjective wool assessment to avoid keeping breeding males with high kemp percentage.

\section{Mean Fiber Diameter and Staple Length}

Wool MFD was 36.9 $\pm 0.5 \mu \mathrm{m}$ (Table 1 ) with an individual sheep range of 22.7-60.0 $\mu \mathrm{m}$ (Table 2). Zandi and Balouchi breed had the finest and longest wool while Mehrabani sheep had the coarsest and shortest with 73\% of wool samples coarser than $37 \mu \mathrm{m}$. While Baluchi and Zandi wool is used in making fine carpets, Mehrabani wool is used in very rough and bulky appearance carpets indicating the need for breeding programs to decrease the fiber diameter and increase the staple length.

Overall fiber diameter of wool in this study is comparable to Middle Eastern carpet wool sheep breeds, $36.0 \mu \mathrm{m}$ for Awassi (Tabbaa et al., 2001), $35.4 \mu \mathrm{m}$ for Ossimi and $31.5 \mu \mathrm{m}$ for Rahmani (Maria et al., 1992), 38.4 $\mu \mathrm{m}$ for Barbary (Akraim et al., 2008) and 39.1-40.2 $\mu \mathrm{m}$ for Karakaya (Cimen, 2006). Even though not significant, males had slightly lower fiber diameter than females. One year old sheep had significantly lower fiber diameter than older sheep. Zandi, Baluchi and Lori sheep with respective MFD of $30.6 \pm 0.7,31.0 \pm 0.4$ and $32.8 \pm 0.8$ $\mu \mathrm{m}$ had the lowest fiber diameter. $22 \%, 36 \%$, and $42 \%$ of

Table 1. Mean ( \pm s.e.) of wool characteristics for different breeds, sexes, and ages

\begin{tabular}{|c|c|c|c|c|c|c|c|c|c|}
\hline & & No & $\mathrm{SL}(\mathrm{mm})$ & $\operatorname{MFD}(\mu \mathrm{m})$ & FDCV (\%) & ICF (\%) & OCF (\%) & KF (\%) & Y (\%) \\
\hline \multirow[t]{2}{*}{ Mean } & & & $110.8 \pm 0.1$ & $36.9 \pm 0.5$ & $50.2 \pm 0.8$ & $84.2 \pm 0.6$ & $9.8 \pm 0.4$ & $5.9 \pm 0.4$ & $69.3 \pm 0.7$ \\
\hline & & & $* *$ & NS & $* *$ & NS & NS & NS & $* *$ \\
\hline \multirow[t]{3}{*}{ Sex } & Male & 75 & $113.7 \pm 0.1^{\mathrm{a}}$ & $36.2 \pm 0.7$ & $47.4 \pm 1.3^{\mathrm{a}}$ & $86.0 \pm 1.0$ & $9.4 \pm 0.8$ & $4.8 \pm 0.6$ & $72.0 \pm 1.0^{\mathrm{a}}$ \\
\hline & Female & 137 & $116.9 \pm 0.2^{b}$ & $37.1 \pm 0.6$ & $51.3 \pm 0.9^{\mathrm{b}}$ & $83.5 \pm 0.8$ & $10.0 \pm 0.5$ & $6.4 \pm 0.5$ & $68.3 \pm 0.9^{b}$ \\
\hline & & & $*$ & * & $* *$ & $* *$ & NS & $* *$ & $*$ \\
\hline \multirow[t]{5}{*}{ Age } & 1 & 53 & $104.7 \pm 0.2^{\mathrm{a}}$ & $34.2 \pm 0.6^{b}$ & $47.2 \pm 1.5^{b}$ & $87.3 \pm 1.2^{a}$ & $8.9 \pm 0.9$ & $3.8 \pm 0.6^{b}$ & $73.4 \pm 1.1^{\mathrm{a}}$ \\
\hline & 2 & 59 & $112.6 \pm 0.2^{b}$ & $38.1 \pm 0.8^{\mathrm{a}}$ & $53.3 \pm 1.1^{\mathrm{a}}$ & $82.0 \pm 1.0^{\mathrm{b}}$ & $10.5 \pm 0.6$ & $7.1 \pm 0.6^{\mathrm{a}}$ & $67.0 \pm 1.2^{\mathrm{b}}$ \\
\hline & 3 & 44 & $113.3 \pm 0.2^{\mathrm{b}}$ & $36.2 \pm 1.0^{\mathrm{ab}}$ & $49.2 \pm 2.3^{\mathrm{ab}}$ & $85.4 \pm 1.7^{\mathrm{ab}}$ & $8.8 \pm 1.0$ & $6.1 \pm 1.0^{\mathrm{a}}$ & $68.7 \pm 1.8^{\mathrm{b}}$ \\
\hline & 4 & 56 & $122.1 \pm 0.3^{c}$ & $37.9 \pm 1.0^{\mathrm{a}}$ & $49.3 \pm 1.6^{\mathrm{ab}}$ & $83.5 \pm 1.4^{\mathrm{ab}}$ & $10.4 \pm 0.9$ & $6.2 \pm 0.9^{a}$ & $69.3 \pm 1.4^{\mathrm{b}}$ \\
\hline & & & * & * & * & * & * & * & * \\
\hline \multirow[t]{5}{*}{ Breed } & Afshari & 68 & $110.7 \pm 0.1^{b}$ & $39.5 \pm 0.6^{\mathrm{a}}$ & $53.6 \pm 1.0^{\mathrm{b}}$ & $77.1 \pm 0.8^{c}$ & $14.0 \pm 0.5^{\mathrm{a}}$ & $8.7 \pm 0.5^{\mathrm{a}}$ & $64.4 \pm 1.0^{\mathrm{a}}$ \\
\hline & Zandi & 21 & $120.0 \pm 0.2^{c}$ & $30.6 \pm 0.7^{b}$ & $43.4 \pm 1.3^{c}$ & $93.7 \pm 1.9^{\mathrm{a}}$ & $6.1 \pm 1.9^{b}$ & $0.8 \pm 0.3^{b}$ & $63.2 \pm 1.6^{b}$ \\
\hline & Mehrabani & 41 & $90.1 \pm 0.1^{\mathrm{a}}$ & $42.1 \pm 1.2^{\mathrm{a}}$ & $60.7 \pm 2.2^{\mathrm{a}}$ & $84.8 \pm 1.4^{\mathrm{b}}$ & $5.5 \pm 0.7^{b}$ & $9.5 \pm 0.9^{a}$ & $76.5 \pm 1.3^{\mathrm{a}}$ \\
\hline & Lori & 31 & $120.9 \pm 0.2^{c}$ & $32.8 \pm 0.8^{b}$ & $39.7 \pm 1.7^{\mathrm{c}}$ & $91.6 \pm 1.5^{\mathrm{a}}$ & $7.4 \pm 1.1^{b}$ & $1.0 \pm 0.5^{b}$ & $74.0 \pm 1.8^{\mathrm{a}}$ \\
\hline & Balouchi & 51 & $130.3 \pm 0.1^{\mathrm{d}}$ & $31.0 \pm 0.4^{\mathrm{b}}$ & $42.8 \pm 1.2^{c}$ & $92.7 \pm 0.6^{\mathrm{a}}$ & $6.1 \pm 0.5^{\mathrm{b}}$ & $1.2 \pm 0.2^{\mathrm{b}}$ & $75.6 \pm 1.3^{a}$ \\
\hline
\end{tabular}

Note: ${ }^{*}$ and ${ }^{* *}$ significantly different at $\mathrm{P}<0.05$ and $\mathrm{P}<0.01$ respectively. $\mathrm{Y}=$ yield, $\mathrm{MFD}=$ mean fiber diameter, $\mathrm{FDCV}=$ coefficient of variation of fiber diameter, $\mathrm{SL}=$ staple length, $\mathrm{ICF}=$ non-medullated inner coat fiber, $\mathrm{OCF}=$ medullated outer coat fiber, $\mathrm{KF}=$ medullated $\mathrm{kemp}$ fiber. 
Table 2. Minimum and maximum values of wool characteristics

\begin{tabular}{|c|c|c|c|c|c|c|c|c|c|}
\hline & & & SL (mm) & $\operatorname{MFD}(\mu \mathrm{m})$ & FDCV (\%) & ICF (\%) & OCF (\%) & KF (\%) & Y (\%) \\
\hline \multirow[t]{4}{*}{ Sex } & Male & Min & 80.0 & 26.7 & 27.7 & 60.0 & 0.5 & 0.0 & 30.9 \\
\hline & & Max & 133.5 & 56.9 & 87.7 & 98.6 & 35.1 & 19.2 & 89.6 \\
\hline & Female & Min & 100.9 & 22.7 & 26.7 & 58.9 & 0.4 & 0.0 & 39.3 \\
\hline & & Max & 147.0 & 60.0 & 88.6 & 99.6 & 31.8 & 33.6 & 88.3 \\
\hline \multirow[t]{8}{*}{ Age } & 1 & Min & 80.0 & 22.7 & 27.7 & 60.0 & 0.4 & 0.0 & 50.2 \\
\hline & & Max & 110.2 & 45.9 & 81.5 & 98.9 & 35.1 & 18.4 & 87.1 \\
\hline & 2 & Min & 100.0 & 25.2 & 30.6 & 58.9 & 0.9 & 0.0 & 39.3 \\
\hline & & Max & 120.5 & 60.0 & 76.2 & 99.1 & 31.8 & 22.9 & 89.6 \\
\hline & 3 & Min & 100.2 & 24.2 & 28.8 & 59.4 & 0.5 & 0.0 & 30.9 \\
\hline & & Max & 127.3 & 56.9 & 87.7 & 99.1 & 24.9 & 21.9 & 86.7 \\
\hline & 4 & Min & 109.6 & 26.7 & 26.7 & 58.9 & 0.4 & 0.0 & 39.4 \\
\hline & & Max & 147.0 & 60.0 & 88.6 & 99.6 & 27.9 & 33.6 & 87.4 \\
\hline \multirow[t]{10}{*}{ Breed } & Afshari & Min & 100.0 & 26.7 & 28.2 & 58.9 & 3.2 & 0.5 & 39.3 \\
\hline & & Max & 130.8 & 60.0 & 82.5 & 95.2 & 31.8 & 28.4 & 86.7 \\
\hline & Zandi & Min & 110.0 & 25.2 & 32.7 & 60.0 & 1.2 & 0.0 & 47.2 \\
\hline & & Max & 140.0 & 38.9 & 54.1 & 99.0 & 35.1 & 4.9 & 74.3 \\
\hline & Mehrabani & Min & 80.0 & 30.7 & 27.7 & 58.9 & 0.4 & 2.3 & 55.7 \\
\hline & & Max & 110.4 & 60.0 & 88.6 & 96.7 & 17.5 & 33.6 & 89.6 \\
\hline & Lori & Min & 110.2 & 25.9 & 26.7 & 67.4 & 0.4 & 0.0 & 52.4 \\
\hline & & Max & 140.4 & 45.7 & 75.9 & 99.6 & 23.1 & 16.3 & 88.3 \\
\hline & Balouchi & Min & 120.0 & 22.7 & 28.9 & 77.9 & 0.5 & 0.0 & 30.9 \\
\hline & & Max & 147.0 & 42.2 & 70.4 & 98.9 & 16.2 & 7.8 & 87.4 \\
\hline
\end{tabular}

Note: ${ }^{*}$ and ${ }^{* *}$ significantly different at $\mathrm{P}<0.05$ and $\mathrm{P}<0.01$ respectively. $\mathrm{Y}=$ yield, $\mathrm{MFD}=$ mean fiber diameter, $\mathrm{FDCV}=$ coefficient of variation of fiber diameter, $\mathrm{SL}=$ staple length, $\mathrm{ICF}=$ non-medullated inner coat fiber, $\mathrm{OCF}=$ medullated outer coat fiber, $\mathrm{KF}=$ medullated $\mathrm{kemp}$ fiber.

Table 3. Classification of the incidence (\%) of sampled wool based on mean fiber diameter (MFD), staple length (SL) and non-medullated inner coat fiber (ICF)

\begin{tabular}{|c|c|c|c|c|c|c|}
\hline & MFD & $\%$ & SL & $\%$ & ICF & $\%$ \\
\hline \multirow[t]{3}{*}{ All Breeds } & $22-30$ & 22 & $<100$ & 12 & $<65$ & 5 \\
\hline & $31-37$ & 36 & $100-120$ & 38 & $65-80$ & 28 \\
\hline & $>37$ & 42 & $>120$ & 50 & $>80$ & 67 \\
\hline \multirow[t]{3}{*}{ Afshari } & $22-30$ & 5 & $<100$ & 0 & $<65$ & 9 \\
\hline & $31-37$ & 36 & $100-120$ & 60 & $65-80$ & 48 \\
\hline & $>37$ & 59 & $>120$ & 40 & $>80$ & 43 \\
\hline \multirow[t]{3}{*}{ Zandi } & $22-30$ & 60 & $<100$ & 0 & $<65$ & 5 \\
\hline & $31-37$ & 35 & $100-120$ & 62 & $65-80$ & 5 \\
\hline & $>37$ & 5 & $>120$ & 38 & $>80$ & 90 \\
\hline \multirow[t]{3}{*}{ Mehrabani } & $22-30$ & 3 & $<100$ & 85 & $<65$ & 5 \\
\hline & $31-37$ & 24 & $100-120$ & 15 & $65-80$ & 15 \\
\hline & $>37$ & 73 & $>120$ & 0 & $>80$ & 80 \\
\hline \multirow[t]{3}{*}{ Lori } & $22-30$ & 35 & $<100$ & 0 & $<65$ & 0 \\
\hline & $31-37$ & 52 & $100-120$ & 10 & $65-80$ & 13 \\
\hline & $>37$ & 13 & $>120$ & 90 & $>80$ & 87 \\
\hline \multirow[t]{3}{*}{ Baluchi } & $22-30$ & 43 & $<100$ & 0 & $<65$ & 0 \\
\hline & $31-37$ & 55 & $100-120$ & 4 & $65-80$ & 4 \\
\hline & $>37$ & 2 & $>120$ & 96 & $>80$ & 96 \\
\hline
\end{tabular}


wool samples had a fiber diameter of 22-30, 31-37, and grater than $37 \mu \mathrm{m}$ respectively (Table 3 ). The impact of age could be associated with larger body size and reduced skin follicle density and competition for nutrients and therefore fiber diameter of older sheep increases. In contrast with the present study, increasing age had no significant effect on fiber diameter in Awassi and Arabi sheep (Tabbaa et al., 2001, Ashmawi \& El-Azzawy, 1980) possibly because the animals were younger.

The overall coefficient of variation of fiber diameter was $50.2 \% \pm 0.8 \%$ (Table 1 ) with an individual sheep range of $26.7 \%-88.6 \%$ (Table 2 ). There was significant difference in the percentage of coefficient of variation of fiber diameter between different sexes, ages and breeds of sheep. A significant effect of sex on coefficient of variation of fiber diameter in sheep of current study is in agreement with the results found in Naeini sheep (Dashab et al., 2006) and Arkhamerino $\times$ Ghezel and Arkhamerino $\times$ Moghani crossbred sheep (Esfandyari et al., 2011). The impact of sex on coefficient of variation of fiber diameter could be associated with hormonal differences between both sexes.

Average wool staple length was $110.8 \pm 0.1 \mathrm{~mm}$ (Table 1) with an individual sheep range of $80-147 \mathrm{~mm}$ (Table 2). Males had significantly shorter staple length than females and one year old sheep had significantly shorter staple length than older sheep. Twelve percent of wool samples had a staple length lower than 100 $\mathrm{mm}, 38 \%$ in the range of $100-120 \mathrm{~mm}$ and $50 \%$ longer than $120 \mathrm{~mm}$ (Table 3). There was significant difference in the staple length of different breeds. Mehrabani and Balouchi breeds had the shortest and longest staple length respectively. The staple length of Iranian sheep breeds of the present study is lower than that of Awassi sheep in Jordan $140.0 \mathrm{~mm}$ (Tabbaa et al., 2001) and Barbary sheep in Libya $120.2 \mathrm{~mm}$ (Akraim et al., 2008) but higher than Arabi (Ashmawi \& El-Azzawy, 1980), Ossimi and Rahmani sheep (Maria et al., 1992). A significant effect of age and sex on staple length is in agreement with Tabbaa et al. (2001).

\section{Fiber Shedding Observation}

Fiber shedding in Afshari breed was noticeable and started from neck extending to belly and rump areas as a result of follicle shutdown. Structure of fiber, inner root sheath and outer root sheath cells in inactive follicles were either absent or disrupted. In such follicles the outer root sheath cells were often columnar and radially or spirally arranged in contrast to the randomly arranged cells in normal follicles.

It was observed that Afshari sheep was the only breed that had fiber shedding. Shedding is also common in double-coated feral sheep such as Merino breed in Arapawa Island (Orwin \& Whitaker, 1984); however the level of shedding which causes complete wool casting in latter breeds is much higher. Smaller secondary follicles which produce finner fibers shutdown prior to larger secondary follicles (Ansari-Renani et al., 2007) which could have a negative impact on fiber diameter.

Shedding in Afshari sheep commenced on the neck, chest and shoulders and spread to the back and rump.
This sequential, bilaterally-symmetric pattern has been also reported in cashmere goats (Ansari-Renani et al., 2011) and camels (Ansari-Renani, 2008, Ansari-Renani et al., 2010). Unlike natural shedding, cortisol injected Merino sheep, shedding of fiber starts from rump and belly areas extending to shoulders (Ansari-Renani et al., 2007).

\section{CONCLUSION}

There are differences between Iranian sheep breeds in the way the fibers they produce which contributes to different fleece characteristics such as fiber diameter, staple length and the level of medullation. Sheep in wool characteristics indicating the potential to improve wool quality and the need for adopting proper management and selection methods.

\section{REFERENCES}

Ahtash, A. E. 2005. Wool characteristics of the Libyan Barbary sheep and factors affecting them. J. Basic Appl. Sci. 15: 158180.

Akraim, F., I. S. Milad, A. A. A. Abdulkarim, \& M. Ganem. 2008. Wool characteristics of Libyan sheep in north-eastern Libya. I. Fiber diameter and staple length. Livestock Research for Rural Development. 20 (8) Article \#18.

Ansari-Renani, H. R., P. I. Hynd, \& A. Aghajanzadeh. 2007. Fleece phenotype influences susceptibility to cortisol-induced follicle shutdown in Merino sheep. Asian-Austra. J. Anim. Sci. 20: 1761-1769.

Ansari-Renani, H. R. 2008. Seasonal hair follicle cycle of Camelus Dromedarious. Pakistan J. Bio. Sci. 11: 410-415. http:// dx.doi.org/10.3923/pjbs.2008.410.415

Ansari-Renani, H. R., M. Salehi, Z. Ebadi, \& S. Moradi. 2010. Identification of hair follicle characteristics and activity of one and two humped camels. Small Ruminant Research. 90: 64-70. http://dx.doi.org/10.1016/j.smallrumres.2010.01. 004

Ansari-Renani, H. R., M. Salehi, Z. Ebadi, S. Moradi, H. R. Baghershah, M. Y. Ansari-Renani, \& S. H. Ameli. 2011. Determination of hair follicle characteristics, density and activity of Iranian cashmere goat breeds. Small Ruminant Research. 95:128-132. http://dx.doi.org/10.1016/j.smallrum res.2010.09.013

Ashmawi, G. M. \& W. El-Azzawy. 1980. Effect of age, locality and system of husbandry on fleece characteritics of Arabi sheep. Egyptian J. Anim. Prod. 20: 179-187.

Cimen, M. 2006. The effect of birth type and sex of lambs on fiber diameter. Res. J. Agric. Biol. Sci. 2: 509-511

Dashab, G., M. A. Edris, A. A., Ghare Aghaji, H. Movasagh, \& M. A. Nilforoshan. 2006. Wool fiber quality of Naeini sheep. Pakistan J. Biol. Sci. 2: 270-276.

Esfandyari, H., A. S. Aslaminejad, \& S. A. Rafat. 2011. Wool Characteristics in the third generation of Arkhamerino $x$ Ghezel and Arkhamerino $\times$ Moghani crossbred sheep. Trop. Anim. Health Prod. 43: 1337-1343. http://dx.doi. org/10.1007/s11250-011-9862-9

Farahvash, T., J. Shodja, A. Rafat, \& A. Keshtkaran. 2010. The effect of bilateral crossbreeding between Arkhamerino and Ghezel sheep on the quality of wool of their $F_{1}$ crosses. Asian Journal of Animal and Veterinary Advances. 6: 397400.

Food and Agriculture Organization of the United Nations. 2010. www.FAOSTAT.com.

International Wool Textile Organization. 1952. The determination of wool fiber thickness by a projection microscope. 
Draft specification. Wool Sci. Rev. 8: 57.

Lupton, C. J., B. A. Freking, \& K. A. Leymaster. 2004. Evaluation of Dorset, Finnsheep, Romanov, Texel, and Montadale breeds of sheep: III. Wool characteristics of F1 ewes. J. Anim. Sci. 82: 2293-2300.

Maria, I. F. M., G. M. Gebriel, \& I. Abou-Fandoud. 1992. Relationships between blood groups and some wool characteristics in Egyption coarse-wool fat-tail sheep. Anim. Prod. 55: 123-127. http://dx.doi.org/10.1017/S000335610003734X

Mehta, S. C., S. K. Choprn, V. K. Singgh, M. Ayub, \& V. Mahrotra. 2004. Production and quality of wool in Magra breed of sheep. Indian Journal of Animal Sciences. 74:792-794.

Ministry of Agriculture. 2009. The role of livestock and poultry production on national economy.

Mokhber, M. 2005. Evaluation of wool characteristics of Arkhamerino $\times$ Ghezel and Arkhamerino $\times$ Moghani crossbred sheep in second generation. Thesis, University of Tabriz, IraN.

Orwin, D. F. G. \& A. H. Whitaker. 1984. Feral sheep (Ovis aries L.) of Arapawa Island, Merlborough sound, and a comparison of their wool characteristics with those of four other feral flocks in New Zealand. New Zealand Journal of Zoology 11: 201-224. http://dx.doi.org/10.1080/0301422 3.1984.10423759

Safari, E., N. M. Fogarty, \& A. R. Gilmour. 2005. A review of genetic parameter estimates for wool, growth, meat and reproduction traits in sheep. Livestock Production Science. 92: 271-289. http://dx.doi.org/10.1016/j.livprodsci.2004.09.003

SAS. 2008. SAS Users Guide. Statistics. Version (6.12 ${ }^{\text {th }}$ Edn.), SAS inst. Inc. Cary. NC.

Tabbaa, M. J., W. A. Al-Azzawi, \& D. Campbell. 2001. Variation in fleece characteristics of Awassi sheep at different ages. Small Ruminant Research. 41: 95-100. http://dx.doi. org/10.1016/S0921-4488(01)00203-6

Wurzinger, M., J. Delgado, M. Numbergi, A. Valle Z'arate, A. Stemmer, G. Ugarte, \& J. Solkner. 2005. Genetic and nongenetic factors influencing fiber quality of Bolivian Llamas. Small Ruminant Research 6:131-139.

Yilmaz, A., M. Ozean, B. Ekiz, A. Ceyhan, \& A. Altinel. 2003. The body weight and wool characteristics of the indigenous Imroz and Kivircik sheep breeds of Turkey. Wool Technology and Sheep Breeding 51:16-23. 